\title{
TERRITORIAL DIFFERENCES IN LIVING STANDARDS IN UZBEKISTAN
}

\author{
Shukhrat Kurbanov BeKmetovich @ ${ }^{1}$, Medetbay Oteuliev Orinbayevich ${ }^{2}{ }^{2}$ \\ ${ }^{1}$ Department of Economic and Social Geography, National University of Uzbekistan named after \\ Mirzo Ulugbek, Tashkent, Uzbekistan \\ ${ }^{2}$ Department of Economic and Social Geography, Karakalpak State University named after Berdakh, Nukus, \\ Uzbekistan
}

Manuscript received: April 26, 2021

Revised version: September 21, 2021

Kurbanov Sh.B., Oteuliev M.O., 2021. Territorial differences in living standards in Uzbekistan. Quaestiones Geographicae 40(4), Bogucki Wydawnictwo Naukowe, Poznań, pp. 63-70. 1 table.

AвSTRACт: The concepts of 'standard of living', 'quality of life' and 'lifestyle' are analysed in a comparative manner. The author has made a rating assessment of the regions of the Republic in terms of living standards based on a set of 10 statistical indicators. As a result, regions of Uzbekistan with a relatively high and relatively low standard of living were identified.

KEYWORDS: standard of living of population, quality of life, lifestyle, socio-economic development, indicator

Corresponding author: Kurbanov Shukhrat Bekmetovich, Economic and Social Geography Department, National University of Uzbekistan named after Mirzo Ulugbek, Tashkent, ZIP Code: 100174, Uzbekistan; e-mail: qurbanov1977@mail.ru

\section{Introduction}

From the first years of independence of the Republic of Uzbekistan, serious attention was paid to improving the living standards of the population, radical reform of the service sector and the formation and development of a new form of government based on the requirements of a market economy. In this regard, the government of the Republic has developed and implemented special programmes, instructions, decisions and decrees on the development of social spheres, which are yielding positive results. In particular, since 1997 it has become a tradition in our country to give each year a unique symbolic name and, on this basis, to determine the development priorities of specific and suitable directions for this year. Most of the year names correspond exactly to the social spheres: mothers and children, doctors, coaches, the elderly, sponsors and the harmoniously developed generation, as well as small business and private entrepreneurship, which in essence determine the living standards of the population.

In Section 4 of the Action Strategy for the five priority development areas of the Republic of Uzbekistan for 2017-2021, approved by the Decree of the President of the Republic of Uzbekistan dated February 7, (2017) No. DP-4947 on the Strategy for the further development of the Republic of Uzbekistan, measures aimed at improving the quality of life and living standards of the population are mentioned. The strategy emphasises the importance of consistently increasing the quality of life, employment and real incomes of the population, improving the social 
protection and health care systems, building affordable housing, prioritising the development and modernisation of road transport, engineering-communication and social infrastructure, education and science, which will improve the living conditions of the population.

Furthermore, the establishment of the Ministry of Economic Development and Poverty Reduction in the country, the original content of the Resolution of the President of the Republic of Uzbekistan dated May 1, (2020) No RP-4702 on the implementation of the rating system of socio-economic development of regions is essentially aimed at improving the living standards of the population.

\section{Aims and objectives}

The aim of the research is to identify interregional differences in the standard of living in Uzbekistan based on a comparative analysis of statistical data. To do this, the following tasks have been identified: (1) analysis of differences between such concepts as 'standard of living', 'quality of life' and 'lifestyle'; (2) establishment of criteria for assessing the living standards of the population; (3) assessment of the rating of the regions of Uzbekistan in terms of the living standards of the population on the basis of statistics for 2019; and (4) analysis of differences in living standards of the population in the regions.

\section{The main part}

In the literature, the standard of living and well-being of the population are expressed using various terms and concepts, for example, the quality of life of the population, the lifestyle of the population, the living standards of the population and so on. Although these concepts are close in content, they differ from each other.

Lifestyle is usually characterised by people's lifestyle, work, health and behaviour (Shchitova 2005). The lifestyle of the population is formed and historically changes under the influence of the place of residence, national traditions and daily activities.

Quality of life is a set of factors that characterises the structure of human needs and level of their satisfaction, its interaction with the socio-economic and natural environment and a sense of life satisfaction (Magomaev 2006). Hence, the well-being of man implies that while his material needs are highly satisfied, he has ample opportunity to make extensive use of the achievements of modern civilisation, science, engineering and technology.

The standard of living refers to the living conditions of the population and satisfaction of their material needs. Here, more quantitative indicators, the size and composition of material supply, income and expenses are of key importance (Mukhiddinov 2009).

This means that while the standard of living reflects the material aspects of the life of the population, the quality of life, in turn, describes and assesses more comprehensively the living conditions of people. In most cases, the standard of living is determined by the material well-being of the population, i.e. the ratio between income and expenditure.

\section{Methods and methodology}

Preliminary research on the living standards, quality of life and lifestyle of the population can be found in the works of the English scientist William Petty (1623-1687). In addition, Francois Quesnay (1694-1774) also tried to assess the real sources of improving the living standards of the population, while Adam Smith (1723-1790) was concerned about the spread of poverty among the working class and argued that an increase in the well-being of the population is natural (Living Standards and Inflation, 2020).

Sahasranaman and Bettencourt (2021), in their scientific work, analysed the population census data in India using the urban scaling system to systematically describe the relative characteristics of Indian urban slums, focusing on attributes of neighbourhoods such as access to basic services like water, sanitation and electricity.

Parshukov et al. (2021) studied the socio-economic sphere of rural life at the level of the region and individual urban districts. The research methodology is based on the use of an index method to collect data describing various aspects of the social well-being of the rural population.

Multi-dimensional poverty was studied in Brazil in 2000 and 2010 based on Demographic 
Census microdata. This research compared traditional monetary poverty estimates with multi-dimensional measures of poverty based on two methods. The first of these is the Alkire-Foster counting identification approach and the second is the Permanyer two-stage poverty identification approach. The two-stage approach provides concepts that complement/replace each other within and across poverty measurements, allowing for a more accurate identification of the population targeted by anti-poverty policies. All methods emphasise significant achievements in overcoming poverty (Stankiewicz Serra et al. 2021).

A group of Russian scientists, in their research, studied the problems concerning the substantiation of indicators of sustainable development in the regions of Russia and the improvement of living standards. A general indicator such as the Human Development Index was used to determine the living standards of the population. The authors present an approach to management in the form of optimisation problems aimed at improving the living standards of the region's population, increasing the likelihood of classifying the region as a high-level one. The problem of optimisation is solved on the basis of the identified relationship between the living standards of the region's population and its socio-economic indicators (Tyrsin, Vasilyeva 2020).

Furthermore, the scientific and methodological basis of the study of living standards and socio-economic development of the regions at the present time has found expression in the scientific research of scientists Abdullaev (1998), Abduramanov et al. (2014), Abdurakhmonov (2009), Dagbaeva (2004), Zhmachinsky and Cherneva (2016), Kondrateva (2019), Magomaev (2006), Mukhiddinov (2009), Ryvkina (1979), Talalushkina (2013), Yumanova (2005), Karimov (2009), Novikova et al. (2020), Stryjakiewicz (2017), Latimaha et al. (2021) and others.

The first system of international indicators of the quality of life of the population was developed in 1960 by the UN. Changes to this system in 1978 covered 12 main groups of indicators (Talalushkina 2013), which are the following:

1. Demographic features of the population (births, deaths, disease, life expectancy etc.)

2. Sanitary and hygienic conditions of life

3. Consumption of food products
4. Housing conditions and the level of provision of long-term consumer goods (cars, refrigerators, televisions etc.)

5. Education and culture

6. Employment and working conditions

7. Income and expenses of the population

8. Cost of living and consumer prices

9. Vehicles

10. Organisation of recreation, physical culture and sports

11. Social security

12. Human freedoms

In addition to the above-mentioned criteria, there is a general section that covers a number of information indicators that, in the opinion of UN experts, are necessary for assessing the quality of life, but do not directly determine its nature. The following indicators are included in this section: national income, GDP per capita and its average annual growth rate; volume and types of social services; expenditures of the population for personal consumption, their composition and the average annual growth rate; population density; providing transport services to the population; operation of means of communication, press etc. Nowadays there are many ways to assess the living standards and quality of life of the population. In this regard, there are two approaches - subjective and objective. The first approach assesses people's level of life satisfaction by themselves. In this assessment, indicators that are not available in official statistics are ascertained based on various observations and by asking respondents to fill out special questionnaires. This type of assessment is unique in terms of its closeness to reality. In our opinion, it is expedient to interpret such estimated indicators in general terms as 'the level of life satisfaction'. The opinions of the people about their needs and living conditions constitute the most reliable source of information regarding their level of satisfaction with life. The level of satisfaction with life is thus determined by the people themselves.

In many countries, the objective method of assessment is widely used in practice. The main focus is on the use of official statistics that reflect the indicators of socio-economic development.

The concept of 'living standards' is very complex and comprehensive, and there can be many indicators that describe it. In this article, in order to assess the living standards of the population of 
the country, the following 10 indicators were selected that have access to official statistics (Table 1):

1. Average gross income per capita (thousand Uzbek sums)

2. Average monthly salary of employees (thousand Uzbek sums)

3. The average amount of pension (thousand Uzbek sums)

4. The number of small businesses per 1,000 population (units)

5. Employment rate (\%)

6. The ratio of the employed and non-employed in the economy $(\%)$

7. Volume of paid services per capita (thousand Uzbek sums)

8. Retail trade turnover per capita (thousand Uzbek sums)

9. Consumer price index (\%)

10. The provision of housing for the population ( $\mathrm{m}^{2}$ per capita)

The total income of the entire population, households (families) and individuals play an important role in determining the standard of living of the population. This means that the higher the income of the population in relation to expenditures, the higher the chances of improving the living standards of the population. According to statistics, in 2019 the total income of the population in the country was 344.7 trillion Uzbek sums and achieved a growth rate of $106.5 \%$ compared to 2018. The total per capita income was 10,266.1 thousand Uzbek sums; the real growth rate was $104.5 \%$. Of course, the regions of the country differ sharply in terms of gross income per capita.

\section{Results and discussion}

It should be noted that the regions with large cities and industrial centres, as well as strategically important production facilities of the Republic, favourable economic and geographical location or developed industry, with a relatively large administrative centre (Tashkent city, Angren, Almalyk, Chirchik, Bekabad, Navoi city, Asaka, Kagan, Mubarek, etc.) occupy the leading positions in absolute and relative indicators. Of course, in such territories, paid, retail services and high incomes are observed. Navoi, Bukhara, Tashkent and Khorezm regions have the highest per capita income in the country (excluding Tashkent city), each with more than 1.0 million Uzbek sums. Relatively low rates can be observed in the Republic of Karakalpakstan and the Fergana region. The total income of the population in these administrative units is about 800.0 thousand Uzbek sums, which is almost twice less than that in the Navoi region. The highest average monthly salary in the regions was 3,379.5 thousand Uzbek sums in Tashkent city (the average salary in the country was 2,324.5 thousand Uzbek sums), 2,962.2 thousand sums in the Navoi region and 2,555.6 thousand Uzbek sums in the Tashkent region. In the Samarkand region it amounted to 1,909.5 thousand Uzbek sums and in the Kashkadarya region - to 1,952.3 thousand Uzbek sums. The lowest rates were in Surkhandarya, Namangan and Fergana regions. In other words, except for the city of Tashkent, Navoi and Tashkent regions, the performance of all regions was lower than the national average. The average wage difference between the population of the highest city of Tashkent and the lowest Surkhandarya region was 1,504.7 thousand Uzbek sums (State Statistics Committee, 2020). A similar situation can be seen in the average pension amount. According to statistics, the total number of people receiving pensions and social benefits in the country amounted to 3,690.3 thousand people, or 1,119.8 per 10,000 of the population. In 2019, the average pension in the country amounted to 640.5 thousand Uzbek sums, with Tashkent city and the Navoi region leading the way, accounting for 844.7 and 830.0 thousand Uzbek sums, respectively. In all regions of the Fergana Valley, the average pension is less than 600.0 thousand Uzbek sums. The highest share is in the Syrdarya, Bukhara and the Karakalpak Republic. The remaining regions do not have drastic differences in this regard.

Another indicator of the standard of living is the number of small businesses per 1,000 population. It is known that the essence of small business and private entrepreneurship is to provide the domestic market with quality, competitive products and create new jobs; and on this basis, it serves as an important criterion in increasing the income of the population. The compactness and mobility of small business, together with its ability to quickly adapt to changes in market conditions and consumer needs, make it the most 
Table 1. Assessment of the rating of the regions of Uzbekistan by a set of socio-economic indicators with respect to living standards (2019).

\begin{tabular}{|c|c|c|c|c|c|c|c|c|c|c|c|c|c|}
\hline \multirow{3}{*}{ No } & \multirow{3}{*}{ Regions } & \multicolumn{10}{|c|}{ Indicators of living standards of population } & \multirow{20}{*}{ 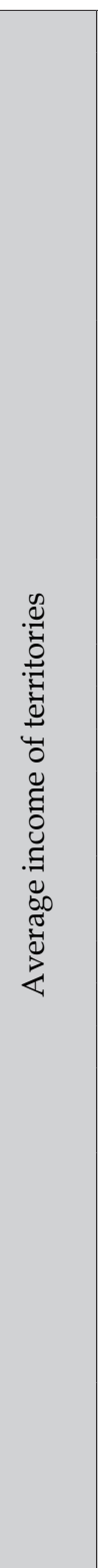 } & \multirow{3}{*}{  } \\
\hline & & \multicolumn{2}{|c|}{$\begin{array}{l}\text { Average } \\
\text { gross income } \\
\text { per capita }\end{array}$} & \multicolumn{2}{|c|}{$\begin{array}{l}\text { Average } \\
\text { monthly } \\
\text { salary }\end{array}$} & \multicolumn{2}{|c|}{$\begin{array}{l}\text { Average pen- } \\
\text { sion amount }\end{array}$} & \multicolumn{2}{|c|}{$\begin{array}{c}\text { Number } \\
\text { of small } \\
\text { busi- } \\
\text { nesses } \\
\text { per } 1,000 \\
\text { popula- } \\
\text { tion }\end{array}$} & \multicolumn{2}{|c|}{$\begin{array}{l}\text { Employ- } \\
\text { ment } \\
\text { rate }\end{array}$} & & \\
\hline & &  & $\frac{\mathscr{\pi}}{\sim}$ & 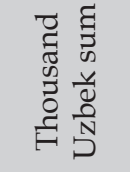 & $\frac{\mathscr{\Xi}}{\sim}$ & 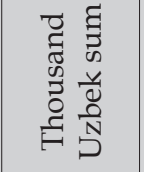 & $\frac{\tilde{\pi}}{\tilde{a}}$ & 密 & $\frac{\mathscr{\sigma}}{\pi}$ & ๑ & $\frac{\tilde{g}}{\sim}$ & & \\
\hline 1 & Karakalpakstan Republic & $7,753.1$ & 14 & $2,172.8$ & 4 & 643.8 & 6 & 11.6 & 8 & 62.9 & 13 & & \\
\hline 2 & Andijan region & $9,671.2$ & 6 & $2,115.2$ & 5 & 552.1 & 14 & 11.4 & 9 & 69.6 & 5 & & 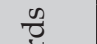 \\
\hline 3 & Bukhara region & $12,723.5$ & 3 & $2,107.1$ & 6 & 654.6 & 5 & 14.9 & 5 & 70.7 & 3 & & \\
\hline 4 & Jizzakh region & $9,366.9$ & 7 & $1,932.9$ & 10 & 581.4 & 11 & 15.6 & 4 & 61.6 & 14 & & \\
\hline 5 & Navoi region & $16,372.4$ & 2 & $2,962.2$ & 2 & 830.0 & 2 & 18.1 & 2 & 69.2 & 6 & & \\
\hline 6 & Namangan region & $8,035.1$ & 12 & $1,876.8$ & 13 & 554.8 & 13 & 10.0 & 11 & 63.8 & 12 & & \\
\hline 7 & Samarkand region & $9,105.4$ & 9 & $1,909.5$ & 11 & 624.7 & 7 & 9.7 & 12 & 66.3 & 7 & & \\
\hline 8 & Surkhandarya region & $8,658.6$ & 11 & $1,874.8$ & 14 & 599.2 & 9 & 8.3 & 13 & 65.2 & 9 & & م. \\
\hline 9 & Syrdarya region & $9,188.1$ & 8 & $1,971.9$ & 7 & 657.6 & 4 & 17.9 & 3 & 70.5 & 4 & & \\
\hline 10 & Tashkent region & $10,401.5$ & 5 & $2,555.6$ & 3 & 694.8 & 3 & 14.9 & 5 & 71.4 & 2 & & \\
\hline 11 & Fergana region & $7,907.4$ & 13 & 1892.2 & 12 & 579.0 & 12 & 12.2 & 6 & 66.0 & 8 & & \\
\hline 12 & Khorezm region & $10,821.1$ & 4 & $1,960.9$ & 8 & 605.3 & 8 & 10.8 & 10 & 64.6 & 11 & & \\
\hline 13 & Kashkadarya region & $8,830.2$ & 10 & $1,952.3$ & 9 & 589.8 & 10 & 11.7 & 7 & 64.8 & 10 & & \\
\hline 14 & Tashkent city & $20,037.5$ & 1 & $3,379.5$ & 1 & 844.7 & 1 & 28.8 & 1 & 77.5 & 1 & & \\
\hline \multirow{3}{*}{ No } & \multirow{3}{*}{ Regions } & \multicolumn{10}{|c|}{ Indicators of living standards of population } & & \\
\hline & & \multicolumn{2}{|c|}{$\begin{array}{l}\text { Ratio of } \\
\text { employed } \\
\text { and under- } \\
\text { employed } \\
\text { population } \\
\text { in economy }\end{array}$} & \multicolumn{2}{|c|}{$\begin{array}{l}\text { Paid services } \\
\text { per capita }\end{array}$} & \multicolumn{2}{|c|}{$\begin{array}{l}\text { Retail } \\
\text { turnover per } \\
\text { capita }\end{array}$} & \multicolumn{2}{|c|}{$\begin{array}{l}\text { Consum- } \\
\text { er price } \\
\text { index }\end{array}$} & \multicolumn{2}{|c|}{$\begin{array}{c}\text { Provi- } \\
\text { sion of } \\
\text { housing } \\
\text { for pop- } \\
\text { ulation }\end{array}$} & & $\begin{array}{l}\text { Do } \\
\text { 壳 } \\
0 \\
0 \\
0 \\
0 \\
0 \\
0\end{array}$ \\
\hline & & $\stackrel{0}{\stackrel{\pi}{\approx}}$ & $\frac{\ddot{\sigma}}{\tilde{L}}$ & 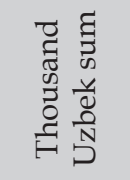 & $\frac{\mathscr{\pi}}{\pi}$ & 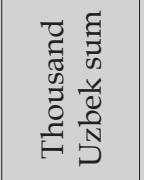 & $\frac{\tilde{J}}{\pi}$ & ه & $\frac{\tilde{\Xi}}{\tilde{\sim}}$ & 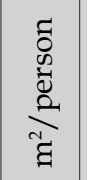 & $\frac{\mathbb{\Xi}}{\tilde{L}}$ & & \\
\hline 1 & Karakalpakstan Republic & 0.62 & 11 & $2,964.0$ & 11 & 2,990 & 14 & 14.6 & 3 & 19.0 & 4 & 8.8 & 9 \\
\hline 2 & Andijan region & 0.73 & 6 & $3,141.6$ & 6 & $4,023.1$ & 7 & 15.4 & 7 & 10.5 & 13 & 7.8 & 7 \\
\hline 3 & Bukhara region & 0.76 & 3 & $4,275.4$ & 4 & $5,383.4$ & 4 & 15.9 & 10 & 16.0 & 6 & 4.9 & 4 \\
\hline 4 & Jizzakh region & 0.58 & 12 & $3,058.6$ & 9 & $4,286.3$ & 5 & 15.5 & 8 & 14.1 & 10 & 9.0 & 10 \\
\hline 5 & Navoi region & 0.74 & 5 & $4,904.9$ & 2 & $6,710.6$ & 2 & 12.9 & 1 & 22.2 & 2 & 2.6 & 2 \\
\hline 6 & Namangan region & 0.64 & 9 & $2,675.5$ & 14 & $3,564.2$ & 11 & 15.1 & 5 & 15.3 & 7 & 10.7 & 14 \\
\hline 7 & Samarkand region & 0.65 & 8 & $3,196.9$ & 5 & $3,586.6$ & 10 & 13.9 & 2 & 15.2 & 8 & 7.9 & 8 \\
\hline 8 & Surkhandarya region & 0.64 & 9 & $2,873.2$ & 12 & $4,227.4$ & 6 & 14.6 & 3 & 12.8 & 12 & 9.8 & 13 \\
\hline 9 & Syrdarya region & 0.77 & 2 & $3,128.1$ & 7 & $3,259.3$ & 12 & 16.0 & 11 & 14.9 & 9 & 6.7 & 5 \\
\hline 10 & Tashkent region & 0.75 & 4 & $4,705.7$ & 3 & $5,968.9$ & 3 & 15.3 & 6 & 15.3 & 7 & 4.1 & 3 \\
\hline 11 & Fergana region & 0.67 & 7 & $3,034.2$ & 10 & 3,635 & 9 & 15.0 & 4 & 13.4 & 11 & 9.2 & 11 \\
\hline 12 & Khorezm region & 0.65 & 8 & $3,065.0$ & 8 & 3,656 & 8 & 15.0 & 4 & 24.1 & 1 & 7.0 & 6 \\
\hline 13 & Kashkadarya region & 0.63 & 10 & $2,691.1$ & 13 & $3,238.7$ & 13 & 15.8 & 9 & 16.9 & 5 & 9.6 & 12 \\
\hline 14 & Tashkent city & 0.85 & 1 & $25,703.0$ & & $14,832.7$ & & 16.6 & 12 & 21.6 & 3 & 2.3 & \\
\hline
\end{tabular}

Source: The table has been compiled by the author on the basis of data from the State Statistics Committee of the Republic of Uzbekistan (2020) and the Central Bank of the Republic of Uzbekistan (2020). 
convenient and acceptable tool for creating new jobs and increasing incomes of the population (Magomaev 2006). At the end of 2019, there was a total of 334,767 small businesses and micro-firms in the country. The share of small business and private entrepreneurship in the country's GDP is 56.5\% (State Statistics Committee, 2020).

There are large regional differences in the number of small businesses per 1,000 population in the Republic. For example, in Tashkent there were 28.8 small businesses per 1,000 population, in the Navoi region-18.1 small businesses per 1,000 population and in the Syrdarya region -17.9 small businesses per 1,000 population. The lowest share was recorded in Surkhandarya, Samarkand and Namangan regions.

Another factor that determines the living standards of the population is the level of employment. According to official data, as of 1 January 2019, the number of economically active population in Uzbekistan amounted to $14,641.7$ thousand people, and the number of people employed in the economy amounted to $13,273.1$ thousand people. The employment rate in the country averaged $67.4 \%$ in the year under review. In this regard, the highest rates are observed in Tashkent city (77.5\%), the Tashkent region $(71.4 \%)$, Syrdarya $(70.5 \%)$ and Bukhara regions $(70.7 \%)$. In the Republic of Karakalpakstan, Jizzakh, Namangan, Khorezm and Kashkadarya regions, employment is low at $65.0 \%$. Based on the analysis of statistical data, it can be concluded that the level of employment is relatively high in regions with relatively industrialised, large industrial centres, resource cities and suburbs. It should be noted that in recent years, the number of people employed in the non-manufacturing sector is growing rapidly. Nearly $80.0 \%$ of those employed were in the non-governmental sector.

In the process of studying the employment of the population, special attention has been paid to determining the ratio of the employed and non-employed in the economy. In this regard, in addition to Tashkent city, Syrdarya, Bukhara and Tashkent regions have high positions. The ratio of the employed to unemployed is 0.77 in Syrdarya, 0.76 in Bukhara and 0.75 in the Tashkent region. Thus, the closer the count is to one here, the more positive the situation. The share of the unemployed is much higher in Jizzakh, Kashkadarya regions and the Republic of Karakalpakstan. The indicators of the remaining regions do not differ sharply from each other.

The ultimate goal of economic development is to improve the living conditions and standard of living of the population, and to consistently solve social problems. In this regard, retail trade, paid services and increasing the income of the population are of great importance. As of 1 January 2020, 398.1 thousand enterprises and organisations operated in the country. Of these, more than 261,000 enterprises and organisations operate in the services sector. This indicator increased by $23.0 \%$ compared to the same period last year. The largest share in the total structure of enterprises and organisations operating in the field of paid services are trade services (33.3\%), accommodation and catering services (9.3\%), transport and storage (6.2\%), information and communication $(3.3 \%)$, health and social services $(3.2 \%)$ and other types $(44.7 \%)$ (State Statistics Committee, 2020). In 2019, only Tashkent city accounted for $34.3 \%$ of the total services provided in the country. Samarkand, Tashkent and Andijan regions each provided more than 5.0\% of the country's total services. The share of the Syrdarya region in this regard is $1.4 \%$, and in the Jizzakh region-it is $2.2 \%$. There are also large regional differences in the volume of paid services per capita. For example, the highest indicator is in Tashkent, amounting to 25,703.0 thousand Uzbek sums, whereas the smallest is in the Kashkadarya region, amounting to 2691.1 thousand Uzbek sums - and the difference is almost 10 times. In general, the volume of paid services per capita is dominated by Tashkent city, Navoi and Tashkent regions and the Bukhara region. Namangan, Kashkadarya and Surkhandarya regions are in the last places.

The retail trade turnover in the country in 2019 amounted to 164,184.2 billion Uzbek sums, an increase of $7.9 \%$ compared to 2018. A total of $74.6 \%$ of retail trade turnover was carried out by small business and private entrepreneurship. When we calculate the retail turnover per capita, we can see a situation similar to paid services. The average per capita income in the country was 4,889.2 thousand Uzbek sums, and in this regard, the capital Tashkent, the Navoi region and the Tashkent region are in the lead. The Republic of Karakalpakstan ranks 14th. 
There are also regional differences in the consumer price index. In this regard, the indicators of Navoi and Samarkand regions are positive, while Tashkent city, Syrdarya, Bukhara and Kashkadarya regions are more problematic.

The provision of housing for the population is also one of the direct expressions of the living standards of the population. When assessing housing conditions, statistics primarily try to identify the homeowner. Therefore, housing is divided into private, rented and municipal housing. The total area of the housing stock in the Republic of Uzbekistan in 2018 amounted to 521.24 million $\mathrm{m}^{2}$. The share of Samarkand, Kashkadarya and Tashkent city in the housing stock is much higher. An indicator of the average or total living area per capita is used to describe the provision of housing for the population. According to the Republican Statistics Committee, $97.9 \%$ of the population has a private yard or apartment. This indicator is $99.3 \%$ of the population living in rural areas (State Statistics Committee, 2020). As can be seen in Table 1 that the Khorezm region has $24.1 \mathrm{~m}^{2}$, the Navoi region has $22.2 \mathrm{~m}^{2}$ and Tashkent city has $21.6 \mathrm{~m}^{2}$ of housing per capita. In the Andijan region $10.5 \mathrm{~m}^{2}$ and in the Surkhandarya region $12.8 \mathrm{~m}^{2}$ of compatible housing is available per person.

From the data in Table 1 it can be seen that the position of each region was determined on the basis of the 10 indicators studied and the average indicator of the position of the regions was derived on the basis of the identified positions. The average position of the regions, in turn, made it possible to determine their overall rating (position) in terms of living standards. In Tashkent city, the average position of the regions was 2.3, taking first place in the overall ranking in terms of living standards. The second place was taken by Navoi; the third place was taken by the Tashkent region. The last places in the overall ranking of living standards belong to Namangan, Surkhandarya and Kashkadarya regions.

In studying the living standards of the population, special attention is paid to the data collected on the basis of special observations, which are difficult to obtain from official statistics. Therefore, the state statistical authorities conduct regular sample surveys. At the same time, tendencies of changes in the provision of durable goods for the population of the republic are studied. Durable goods include personal cars, televisions, refrigerators, vacuum cleaners, washing machines, air conditioners, personal computers and mobile phones. Usually, they are determined by how many fit per 100 or 1,000 households (kun.uz news 2020)

\section{Conclusion}

The standard of living of the population reflects the material aspects of human life, while the quality of life describes and evaluates people's living conditions in a more complex way. In most cases, the standard of living is determined by the material well-being of the population, i.e. the ratio between income and expenditure. As a result of the study, the criteria for assessing the living standards of the population of the regions of Uzbekistan were selected and based on them, the positions of the regions in the country were determined. On the basis of the identified places, the overall ranking of the living standards of the regions was determined.

The analysis shows that Tashkent city, Navoi, Tashkent and Bukhara regions are leaders in terms of living standards among the regions of the country and are much ahead of other regions. At the same time, Fergana, Kashkadarya, Surkhandarya and especially Namangan regions are lagging far behind. Therefore, in implementing measures aimed at improving the living standards of the population and reducing poverty, which are currently being carried out on a large scale in our country, it is expedient to give priority to these regions.

\section{Acknowledgments}

We would like to thank language editors for their feedback which helped to improve the quality of the article.

\section{References}

Abdullaev Yo., 1998. Macroeconomic statistics. Publishing House of Mehnat, Tashkent: 382 (in Uzbek).

Abdurakhmonov Q.Kh., 2009. Labor economics. Publishing House of Mehnat, Tashkent: 357 (in Uzbek).

Abduramanov Kh.Kh., Arabov N.U., Kholmukhamedov M.M., 2014. Population income and quality of life. Tafakkur Bostoni Press, Tashkent: 256 (in Uzbek). 
Dagbaeva S.D.N., 2004. Living standards of the population: Ways of solving the problem of poverty. VSGTU Publishing House, Ulan-Ude: 146 (in Russian).

Decree of the President of the Republic of Uzbekistan of February 7, 2017 No DP-4947 on the action strategy for further development of the Republic of Uzbekistan (in Uzbek). Online: https:// nrm.uz/contentf?doc $=491373$ _o \% E2 \% 80\%98zbekiston_respublikasi_prezidentining_07_02_2017_y_ pf-4947-son_o\%E2\%80\%98zbekiston_respublikasini_ yanada_rivojlantirish_bo $\%$ E2\% $80 \% 98$ yicha_harakatlar_ strategiyasi_to $\% \mathrm{E} 2 \% 80 \% 98 \mathrm{~g} \% \mathrm{E} 2 \% 80 \%$ 98risidagi_farmoni\&products=1_vse_zakonodatelstvo_uzbekistana

Decree of the President of the Republic of Uzbekistan DP5975 of March 26, 2020 on measures to radically update state policy in the field of economic development and poverty reduction (in Uzbek). Online: https://lex.uz/ docs $/ 4776669$

Information-analytical data, 2020. Living standards and inflation. Central Bank of the Republic of Uzbekistan, Tashkent, Uzbekistan (in Uzbek). Online: https://cbu. uz/upload/iblock/926/Turmush_darazhasi_va_inflyatsiya.pdf

Karimov I.A., 2009. The global financial and economic crisis. Ways and measures to eliminate it in the context of Uzbekistan. Tashkent, Uzbekistan: 46 (in Uzbek).

Kondrateva O.A., 2019. Analysis of the rating of the level and quality of life of the population of the countries of the world. Economic Security and Quality 1(34): 44-48 (in Russian)

Latimaha R., Ismal N.A., Bahari Z., 2021. Cost of living and standard of living nexus: The determinants of cost of living (Hubung Kait Kos Sara Hidup dengan Taraf Hidup: Faktor Penentu Kos Sara Hidup). Jurnal Ekonomi Malaysia 54(3): DOI: 10.17576/JEM-2020-5403-01. Online: https:/ / www.scopus.com/inward/ record.uri?eid $=2$-s2.085099437398\&doi=10.17576\%2fJEM-2020-5403-01\&partnerID $=40 \&$ md5 (accessed: 14 April 2021).

Living Standards and Inflation, 2020. Information-analytical information. Central Bank of the Republic of Uzbekistan, Tashkent (in Uzbek).

Magomaev M.M., 2006. Quality of life of the population (theo$r y$, methodology and mechanisms). Publishing House of the DSC RAS. Makhachkala: 342 (in Russian).

Mukhiddinov Kh.S., 2009. Improving the living standards of the population of the region and modeling social development. Fan Press, Tashkent: 152 (in Uzbek).

Novikova M., de Fátima Ferreiro M., Stryjakiewicz T. 2020. Local development initiatives as promoters of social innovation: Evidence from two European rural regions.
Quaestiones Geographicae 39(2): 43-53. DOI 10.2478/quageo-2020-0012.

Parshukov D.V., Shaporova Z.E., Koloskova Y.I., 2021. Study of the socio-economic living conditions of the rural population of the Krasnoyarsk Territory. IOP Conference Series: Earth and Environmental Science 677(2), art. no. 022051. DOI 10.1088/1755-1315/677/2/022051.

Resolution of the President of the Republic of Uzbekistan of May 1, 2020 No RP-4702 on the implementation of the rating system of socio-economic development of regions.

Ryvkina R.V., 1979. The lifestyle of the rural population. Nauka Press, Novosibirsk: 351 (in Russian).

Sahasranaman A., Bettencourt L.M.A., 2021. Life between the city and the village: Scaling analysis of service access in Indian urban slums. World Development 142, art. no. 105435. DOI 10.1016/j.worlddev.2021.105435.

Shchitova N.A., 2005. Geography of lifestyle: Theory and practice of regional research. Doctoral dissertation in geographical sciences of Geographical Sciences. Moscow: 334 (in Russian).

Stankiewicz Serra A., Yalonetzky G.I., Maia A.G., 2021. Multidimensional poverty in Brazil in the early 21st Century: Evidence from the Demographic Census. Social Indicators Research 154(1): 79-114. DOI 10.1007/s11205-020-02568-5.

State Statistics Committee of the Republic of Uzbekistan, 2020. Online: www.stat.uz (accessed: 24 December 2020).

Stryjakiewicz T., 2017. Urban shrinkage in East-Central Europe. XI Сократические чтения: Жан Готтманн как провидец и критик (к столетию со дня рождения). Materials of the international scientific conference "Spatial transformation of the urbanized environment in the conditions of post-industrial development of society" 31-46. Online: https://www.researchgate.net/publication/329450774_Prostranstvennaa_transformacia_urbanizirovannoj_sredy_v_usloviah_postindustrialnogo_ razvitia_obsestva (accessed: 14 April 2021).

Talalushkina Yu.N., 2013. UN experience in the study of the quality of life of the population. Economic Journal 31(3): 46-53 (in Russian).

Tyrsin A.N., Vasilyeva E.V., 2020. Sustainable development indicators in benchmarks of Russia's regional policy. IOP Conference Series: Earth and Environmental Science 534(1), art. no. 012003. DOI 10.1088/1755-1315/534/1/012003.

Yumanova U.V., 2005. Territorial differentiation of the standard of living of the population in the regional settlement system: The example of Chuvashia. Dissertation candidate of geographical sciences. Moscow: 199 (in Russian).

Zhmachinsky V.I., Cherneva R.I., 2016. Methodology for assessing the standard of living of the population. Economic Analysis: Theory and Practice 9: 55-66 (in Russian). 